\title{
The Paradoxes of Humanitarian Aid
}

\author{
Fiona Terry
}

D URING the 1990s, an increase in the occurrence of humanitarian disasters has led aid organisations to expand their emergency response capacities, and the allocation of government funds and private donations to emergencies has reached unprecedented levels. Development assistance, which focuses on longer-term economic, political and social improvements in the well-being of poor or vulnerable communities, has stagnated in many parts of the world, while humanitarian aid, which aims to alleviate life-threatening suffering and help communities traverse periods of crisis (Brauman, 1995:10), has become the most common form of aid in states deemed to have collapsed.

Australia has followed this global trend. By 1993/94 emergency relief activities had become the largest area of Australian Agency for International Development (AusAID) funding to non-government organisations (NGOs), representing 38 per cent of total aid allocations (AusAID, 1995:10). Total multilateral and bilateral emergency aid grew from US\$40.1m in 1988 to US\$54m in 1991 (AIDAB, 1994:89). Hence, emergency relief represented 5.4 per cent of total official development assistance in 1995/96 (Downer, 1997), up from 3.6 per cent in 1988 (AIDAB, 1994:89). But in spite of this increase in emergency activities, Australian aid organisations, both government and non-government, remain intellectually focused on development. Little debate takes place in Australia about the impact of emergency operations and ways in which aid agencies can improve the effectiveness and efficiency of their interventions. Characterised by the rapidity of the response, the scale of the problem, and notions of 'complexity', 'chaos', and 'anarchy', emergency aid operations are often excused from the scrutiny which is accorded to development programs.

In this article, it is suggested that this lack of debate reflects a culture of justification surrounding Australian aid and the language associated with humanitarian crises. The extent to which humanitarian aid can have unintended negative consequences is illustrated, and the effectiveness of AusAID's mechanisms for ensuring that Australian aid does not have harmful consequences is examined.

Fiona Terry is a postgraduate student at the Peace Research Centre, The Australian National University, and President of the Australian branch of Médecins Sans Frontières (MSF). The views expressed in this article are those of the author and not necessarily those of MSF. 


\section{The Australian Non-Debate in a Culture of Justification}

According to Hobbs and Goldsworthy (1996:xx), humanitarian aid programs, while important, 'do not fit well with the broader policy which drives the [Australian aid] program and are largely reactive in nature'. In the same vein, the Committee of Review of the Australian Overseas Aid Program (which in 1997 produced the Simons Report) admits that it was not able to examine in depth the issues affecting 'complex emergencies'. It visited only one emergency setting, a well-established refugee camp on the Kenya-Somalia border. Nevertheless, it characterised emergency situations by their 'complexity, speed and confusion' and recommended that 'while immediate relief aid is essentially a reactive element of the overall aid program, longer-term rehabilitation support does lend itself to programming, critical assessment and evaluation ... and should be managed in this way' (Committee of Review of the Australian Overseas Aid Program, 1997:279). This statement implies that emergency aid need not undergo the critical assessment and evaluation to which rehabilitation and development programs are subject.

The complexities of providing humanitarian aid are not openly discussed in Australia in part because the provision of assistance to underdeveloped or disasterprone countries is not universally believed to be a moral duty or in the interests of Australia. The general public is largely unaware of the economic, moral, political and strategic arguments for and against the provision of aid; and the government aid budget and independent NGO activities must be justified to taxpayers and private donors in terms which will be understood and supported by the average citizen. For example, the AusAID web site shows that, out of each $\$ 100$ of government spending, only $\$ 1.20$ is spent on aid, compared with, inter alia, $\$ 36$ on social security and welfare, and $\$ 8$ on defence; it further justifies this amount by stating that most of it is spent on goods and services in Australia which are then sent to where they are needed overseas (AusAID, 1997a).

Aid agencies are compelled to present their activities in a positive light and to highlight the successes, but not the failures, of aid projects. Since the public, upon which aid agencies are so dependent, may stop giving at the slightest suggestion that their money is not having the intended effects, failures are downplayed with the excuse that 'at least we tried'. As a senior NGO representative was quoted as saying in Ethiopia,

You can't confuse the public with complex issues. Starving babies and droughts are something people can understand. But trying to explain corruption or aid abuses is not going to help our fund-raising and will only hamper our work. (Girardet, 1993:46)

Yet aid organisations owe their beneficiaries an honest discussion about the dilemmas of humanitarian aid. The Australian government spent $\mathrm{A} \$ 84 \mathrm{~m}$ on emergency relief in 1995/96 (Committee of Review of the Australian Overseas Aid Program Simons Report, 1997:281). In addition, NGOs raise millions of dollars from the Australian public; $\$ 30 \mathrm{~m}$ was raised for the Rwandan crisis alone in 1994 
(Committee of Review of the Australian Overseas Aid Program, 1997:284). The revenue raised and allocated to disasters, although the most visible component of the response to the Australian public, is only the first step; the provision of aid does not automatically lead to the alleviation of suffering. It is only through recognising that aid can have ambiguous outcomes that aid organisations can attempt to minimise the negative aspects of their work.

\section{'Complex Emergencies' and the Paradoxes of Humanitarian Aid}

The provision of aid in an emergency situation, whether a natural disaster or the consequence of war, can result in outcomes which were not originally intended. These are not always negative, but the paradox of aid lies in the fact that sometimes aid itself can play a role contrary to that which is anticipated. The paradoxical consequences of aid tend to be heightened in situations of conflict, where aid can become a stake in war, often without the cognisance of aid organisations. In the past few years, however, European humanitarian agencies in particular have begun to wonder whether their impact in conflict zones is at best marginal or a part of the problem at worst.

The language used to describe humanitarian crises, and the emphasis placed on differences in the global environment between the Cold War and the post-Cold War periods, tend to depict the current dilemmas of humanitarian aid as an unavoidable by-product of the 'new world order'. 'Complex emergencies' is the fashionable euphemism for post-Cold War humanitarian crises, and accompanies notions of 'chaos', 'anarchy' and 'mindless violence' which 'new barbarism' theses (Richards, 1996:xiv-vii) like those of Robert Kaplan (1994) espouse. The term 'complex emergency' is designed to associate the multiple causes of disasters with the multi-faceted direct or indirect consequences, such as large population displacement, famine, and significant mortality (Burkholder \& Toole, 1995:1012). The term has been thrust to the fore of emergency response jargon to reflect the need for a broad and integrated response which, for the United Nations, requires a system-wide effort (Duffield, 1994:38).

The complexity of emergencies, however, seems to have more to do with the response of the multiplicity of actors in the humanitarian field than with differences in the causes of suffering between the Cold War and the post-Cold War periods. Humanitarian actors have proliferated greatly since 1990 and each aid agency is armed with a different self-imposed mandate, competing with others for a share of the relief budget. Evaluation reports of emergency operations invariably call for more coordination among agencies in these times of 'complex' problems, a call which is certainly valid. But the causal emphasis is placed on the changed environment in which aid is provided rather than the aid effort itself, and permits aid agencies to excuse failures in this 'anarchic' and 'chaotic' context. Furthermore, this differentiation of Cold War emergencies from post-Cold War emergencies allows aid organisations to minimise the relevance of the lessons of the past.

While the end of the Cold War altered certain aspects of the provision of aid (elaborated below), the paradoxes of humanitarian action and the causes of suffer- 
ing remain fundamentally the same. In fact, it was the lack of acknowledgment of the perverse effects of aid, or, in some cases, an overt misuse of the 'humanitarian' nature of aid during the Cold War which has hampered an earlier analysis of the paradoxes of aid. A review of the most significant and publicised relief efforts of the last 30 years shows that aid situations are invariably complex and pose fundamental dilemmas for aid organisations. The 1967 declaration of independence of the province of Biafra from Nigeria, for example, provoked a civil war in which $\mathrm{Ni}$ geria blockaded the secessionists' territory, provoking widespread famine. The Nigerian government restricted aid organisations' access, and more than a million people are thought to have perished. When aid organisations gained admittance, the secessionists were facing military defeat. The Biafran insurgents then used the famine to turn public opinion in their favour, and became increasingly intransigent in negotiations with the government at the expense of their own people. The world's first televised famine generated unprecedented sympathy for the victims of Nigerian oppression and the aid and media networks became a tool in the hands of General Ojukwu.'

Similarly, the 1984-85 emergency in Ethiopia was not unicausal, as the opposite of 'complex' implies, but was a result of government policies combined with drought. As in Nigeria, aid had unintended consequences, inadvertently supporting the government policy of forced relocation of villagers living in the north. People were attracted by aid to the 'displaced camps' established by humanitarian organisations, which became 'relocation camps' for the government. Of 800,000 people moved to marginal land in the south, some 200,000 died (Brauman, 1997:xxiii).

Although the paradoxes of humanitarian aid are not new, the end of the Cold War has altered the way in which conflicts are fought and increased the visibility and thus the stakes of humanitarian aid in war. Adherence to state sovereignty has diminished, and external interference in a nation's affairs is defended on humanitarian grounds: hence the military-humanitarian interventions in northern Iraq, Somalia, the former Yugoslavia, Haiti and Rwanda. Aid organisations, relegated to refugee camps on the periphery of conflicts during the Cold War, have since gained access to the heart of conflicts. In these predominantly internal conflicts which are free of the East-West ideological context, combatants have adopted strategies which Jean-Christophe Rufin (1996) calls 'predation' and 'criminalisation' in pursuit of war. Lacking patronage from above, belligerents prey on the local inhabitants for sustenance, and make economic resources and infrastructure their target. In Liberia and Sierra Leone, for example, villages are subjected to looting sprees and terror, and government and rebel forces fight over diamond mines. Charles Taylor funded the National Patriotic Front of Liberia for over six years through 'criminalisation' practices; within only six months of the launch of his offensive in

\footnotetext{
I This analysis is limited to the implications of humanitarian aid in the Biafran war. It is not intended as a comment on the justness of the Nigerian or Biafran cause, which is beyond the scope of this article. 2

The extent to which sovereignty has eroded is a contentious issue and is beyond the scope of this article. See Camilleri and Falk (1992) and James (1995) for aspects of the debate.
} 
Liberia, his movement had earned over US\$3.6m from timber exports to the EC (The Guardian, 25 June 1991). Opium in Afghanistan, precious stones in western Cambodia, and gold in Zaire serve the same purpose for rebel factions.

Humanitarian aid carried into the heart of conflict becomes a target of 'predation' and 'criminalisation'; since humanitarian supplies are invariably the largest external resource arriving in a war zone, control of aid becomes an objective in itself. When convoys are robbed and protection payments made to secure roads, vehicles, houses or airports, this finance sustains the economy of the war. Through establishment of checkpoints and imposition of taxes, armed groups can ensure that their soldiers are fed or paid. In ex-Yugoslavia, the Serbs appropriated some 30 per cent of aid destined for Sarajevo; in Mozambique, a tax of $\$ 150$ per tonne was levied on all aid flights to the interior; in Somalia, hundreds of dollars a day were paid for permission to land relief flights at Baidoa airport; and in Iraqi Kurdistan, the official exchange rate imposed on the UN contributed US $\$ 250 \mathrm{~m}$ to the Iraqi budget in 1992 alone (Jean, 1996:568-70).

Humanitarian aid can become a tool in the control of populations since needy people will move to the site of aid if possible, and if not, humanitarian aid will try to move to them. In Liberia, factions held populations hostage, preventing them from leaving in order to attract aid to their region. In Bosnia, humanitarian organisations were caught in a deep dilemma: to bring aid to towns encouraged the occupants to stay, thereby risking their safety at the hands of the opposition, but to encourage them to leave was to comply with the objectives of 'ethnic cleansing'. In the Rwandan refugee camps in Zaire and Tanzania, aid directly empowered the refugee leadership, many of whom were accused of genocide, by giving them the reins of the distribution networks through which they exerted control over the refugees, and discouraged repatriation to Rwanda.

Humanitarian aid, through the services it brings, can also confer on individuals or regimes in situations of conflict a degree of legitimacy, both with their own people and (if the world's media are present) internationally.

But perhaps the most profound paradox of humanitarian aid is the camoutlage it can provide to politicians for their indifference to the causes of the crises that create the need for humanitarian assistance. Wars are political and need political solutions. Politicians are reluctant to become directly involved in crises that do not affect their national interests; but, to appease their domestic constituencies, they need to appear to be addressing the problem. Humanitarian aid allows them to do this. When French President Mitterrand was asked what he was doing to stop the Rwandan genocide, he said that the government was allocating funds to two humanitarian aid agencies. This, and inaction on the part of the international community as a whole, prompted Médecins Sans Frontières to launch a campaign proclaiming that 'you cannot stop a genocide with doctors'.

Unless humanitarian organisations become more outspoken and resist allowing themselves to be made substitutes for political action, they risk becoming accomplices in the deception. Unfortunately, many agencies nowadays are either too financially dependent upon governments and the UN to confront the issue, or risk 
jeopardising their providers of independent revenue if they question the notion that 'something is being done'. The greatest challenge to humanitarian organisations today is to minimise such paradoxes. Yet despite general acknowledgment by agencies of the role refugee camps along the Thai-Cambodian border played in the survival of the Khmer Rouge, the same mistakes were made in the Rwandan refugee camps of Tanzania and Zaire. Why are the lessons of the past not heeded? Part of the answer may be that the documents like the Simons Report and the Australian Council for Overseas Aid (ACFOA) Code of Conduct stress the need for accountability to donors and taxpayers, but pay insufficient attention to accountability to the beneficiaries of assistance programs themselves.

There is no global body to judge whether an NGO's activities are appropriate or efficient. It is difficult to envisage a global regulatory agency which embodies the moral standards to which agencies should adhere, or the appropriate way in which aid should be delivered. But at least donor governments should be aware of the wider impact of the aid programs they finance. They have the power to stop funding a project which is detrimental to the beneficiary population, and they can pose questions about the broader impact of a project which may stimulate introspection on ways in which the negative consequences of aid can be minimised.

\section{Monitoring Australian Humanitarian Aid}

According to the Simons Report, emergency assistance 'is the part of the [Australian] overseas aid program that has the most visibility and receives the most public attention' (Committee of Review of the Australian Overseas Aid Program, 1997:279). 'Thus one would assume that assurances of its effectiveness and appropriateness would be a priority for AusAID. The 1994 Government Review of Humanitarian Relief Programs, however, admits that there is little field monitoring of the activities supported by AusAID (formerly Australian International Development Assistance Bureau, AIDAB) other than through the implementing agencies themselves (AIDAB, 1994:vii), and concluded that increased resources need to be devoted to field monitoring of humanitarian relief programs both by AusAID staff abroad and in Canberra. But a recent evaluation of the extent to which the 1994 review's suggestions have been adopted by AusAID found that no additional resources have been devoted to field monitoring, and that new administrative procedures exclude provisions for field monitoring visits. It also found that the prevailing view in AusAID is that the Humanitarian Relief (HUR) Section does not have the resources to monitor projects directly, and that it is more effective to monitor the monitoring process established by implementing partners such as NGOs (Broughton, 1996a:7).

This raises the question whether such reviews are merely cosmetic rather than serving the requirements of transparency and accountability. Whatever the case, the relatively small size of the aid budget necessitates decisions on the cost-benefit analysis of Australian aid, and the establishment of firm priorities. Resources allocated to monitoring and evaluation processes will divert funds from potential projects in the emergency response operation. However, as Peter Urban (1997) argues 
in a critique of the Simons Report, the aid program needs to include delivery efficiency in its definition of aid effectiveness, and this is possible only through the establishment of a framework through which aid policies can be assessed.

The recent 'NGO reform package' introduced by AusAID (1997b:137-75), however, is aimed at reducing administrative processes for AusAID officers, by increasing the responsibility for approved management procedures and financial accountability to NGOs, at least on paper. NGOs must undergo an accreditation process to show that they can responsibly manage AusAID funds. While this exercise has assisted NGOs to develop thorough accounting procedures and reporting formats, and has been appreciated by the majority of NGOs (Hunt, 1997), little attention is paid to assessment or evaluation of the overall impact of aid projects. The reform authorises NGOs to evaluate their own projects; in effect, if the reporting criteria are satisfactorily met, AusAID requirements will be fulfilled.

AusAID has delineated two levels of accreditation: 'base level', which entails an NGO appraisal in Australia and for which the ceiling of funding is $\$ 100,000$; and 'full accreditation', for which a more detailed NGO assessment is required. The HUR section has a funding floor of $\$ 150,000$, thus necessitating full accreditation for access to this scheme. The full accreditation procedure consists of three phases. The first phase is conducted at the desk level and examines the NGO's structure, experience and philosophy, partnership arrangements, links with the Australian community, and management and financial systems. The second phase involves an examination of the same criteria at the premises of the NGO, based on physical evidence. The third phase involves a field visit to an overseas program to ensure compliance with the same criteria on the ground.

While the appraisal of the project management and financial structures of NGOs and their partners is fairly rigorous, very little emphasis seems to be placed upon the broader aspects of aid. Examination of the philosophy of NGOs is limited to ensuring that their development philosophies are not inconsistent with the objectives of the Australian aid program, hence leaving scope for interpretation. Ethical dimensions of the provision of aid are addressed through the requirement that NGOs be signatories to the ACFOA Code of Conduct, and formally adopt the provisions therein. But, as executive staff of ACFOA will admit, the Code of Conduct itself is oriented towards the rights of donors, not the need of beneficiaries to receive appropriate aid which will not have adverse effects.

The crux of the ACFOA Code of Conduct is transparency in advertising and financial accounting, not operational activities. Although the Code has instituted a complaints and compliance process to improve self-regulation of the aid industry, the culture of justification is likely to impede all but petty charges from entering the complaints system. In fact, in the year since the Code was adopted, no complaint has been formally lodged (Hunt, 1997). The repercussions of the allegations against CARE Australia in 1995 affected the entire aid industry; public confidence in NGOs diminished. Perhaps the need for a public show of solidarity explains why members of ACFOA, at the same annual meeting at which they unanimously adopted the Code of Conduct in 1996, welcomed CARE into the ACFOA fold 
without one question publicly raised as to the status of CARE's efforts to clear its name. Detailed questions may have been raised in private, but the irony of the situation was not lost on external observers present.

The HUR section of AusAID, however, has moved closer to considering accountability to beneficiaries as well as donors by obliging NGOs to adhere to the principles specified in the 'Code of Conduct for the International Red Cross and Red Crescent Movement and NGOs in Disaster relief. This Code is oriented towards guarding standards of behaviour in emergencies which relate to independence, effectiveness and impact. The Code specifies ways in which beneficiary communities should be respected, and includes a clause stating that the negative impacts of humanitarian assistance should be minimised. But, to highlight the need for debate on aid issues, the Code puts the 'humanitarian imperative' first, stating that it is the obligation of humanitarian agencies to provide humanitarian assistance wherever needed. It thus denies the possibility that aid may not always be in the best interests of the recipients. The example of Bosnia mentioned above raises the question as to whether aid encouraged people to stay in enclaves which were then attacked by opposing forces. The aid at least gave people the choice of staying or leaving; but are aid organisations sufficiently aware of the possible consequences of their operations?

The Code is effective in increasing awareness of the principles and ethics to which aid organisations should adhere. Like the ACFOA Code of Conduct, however, it has no independent regulatory body, but is 'enforced by the will of the organisation accepting it to maintain the standards laid down in the Code' (IFRC, 1997:144). The Codes are thereby fraught with the same limitations as international law; states sign and ratify treaties and conventions, but cannot be made to observe them. Heads of agencies may agree that their organisation will adhere to the principles established, but this does not obviate the need for scrutiny by donors. The clear standards of operations contained in the Code provide benchmarks which AusAID could use in assessing the broader aspects of NGO humanitarian aid delivery.

With NGO accreditation criteria, and AusAID evaluation criteria as a whole, the measure by which 'effective overseas work ... consistent with the objectives of the Australian Aid Program' (AusAID, 1997c) is judged raises questions. Effectiveness, according to the Department of Finance and the Auditor-General, is measured by the extent to which the program outcomes achieved the stated objectives (ANAO, 1996:20). AusAID sets objectives which can be quite general, or can astutely direct Australian aid away from problematic areas: witness the Australian focus towards repatriation and rehabilitation in Rwanda instead of aid to the Rwandan refugee camps. Once individual project objectives have been approved by AusAID and funding granted, however, the evaluation of that project is based upon the ex-

3

CARE Australia has received full-level accreditation. A response to the allegations was issued by the Minister of Justice only on 24 December 1997, more than two and a half years after the allegations were made (Joint Statement by CARE and AusAID, 24 December 1997). 
tent to which the original project objectives were met. While the evaluation format includes contextual considerations which may have hampered the fulfilment of the project objectives, the overall impact or implications of the project can easily be overlooked. Thus, a project aiming to reduce malnutrition rates in a food deficit area may statistically meet the objectives. But the impact that the introduction of food may have on local prices, and hence on the incentive for farmers to produce food locally, may not be taken into account. Broughton (1996b:1) found that no humanitarian food aid project has ever been formally evaluated by AusAID, which has relied upon the reports submitted by NGOs and UN agencies.

AusAID's preference for strengthening the desk-level supervision of NGO projects over direct field monitoring seems to be contrary to trends in other parts of the world. The European Community Humanitarian Office, for example, sent individual sectoral specialists to Liberia in 1995 to examine projects. While micromanagement is inappropriate, these specialists made beneficial contributions to project design and implementation, and provided weight in difficult negotiations with uncooperative local authorities and factions. In a different role, it was staff of the Office of Foreign Disaster Assistance of the US Agency for International Development who acted as moderators in Somalia between the US troops and NGO personnel. They helped to steer military activities in directions which would complement rather than compete with NGO activities, and coordinated regular meetings among the various actors.

Budgetary constraints necessitating choices between evaluations or field operations can be eased through collaboration with other donors. The Joint Evaluation of Emergency Assistance to Rwanda, proposed by the Danish Ministry of Foreign Affairs, involved contributions from some 18 governments, and was influential in addressing shortcomings of the Rwandan relief effort. Donor governments could replicate this cooperation, perhaps on a geographical basis, to reduce the cost of sending evaluation teams throughout the world.

In order to fulfil such roles, however, Aus AID staff and consultants need to have legitimacy, and be respected by experienced relief staff beyond controlling the purse-strings of field operations. If AusAID staff are to make sound judgments about the effectiveness and appropriateness of NGO programs, they need to possess the technical, practical and contextual skills with which to advise NGOs of the strengths and weaknesses of emergency activities. The drought relief program in Papua New Guinea (PNG) will be a good test case, with AusAID staff on the ground coordinating the Australian relief effort with local authorities. They face many obstacles: remote communities separated by mountainous terrain makes the logistics of relief problematic. Aircraft visibility was compromised by smoke from the bush-fires, and transportation along some of the major roads is fraught with insecurity. Population statistics are based on the 1990 census which, in addition to being eight years old, is widely believed to be inaccurate. Thus baseline data needed to calculate mortality and morbidity rates, essential to an efficient and effective response, are absent. According to reports from Australian Defence Force personnel, few mechanisms have been organised to ensure the equitable distribution of 
food off-loaded on to airstrips, and the absence of beneficiary lists means that monitoring and evaluation of the relief deliveries will be extremely difficult. Furthermore, the inaccessibility of the terrain hinders aid delivery to individual villages, encouraging people to move to delivery sites. Congregations of people in limited areas could increase public health risks associated with shortages of potable water, lack of sanitary facilities, and the potential spread of communicable diseases.

The PNG drought response has started before crude mortality rates are at the level used by international humanitarian organisations to define an emergency. Thus, compared with the immediate life-saving response needed for the cholera epidemic in Goma, Zaire, or to the bombardment of Grozny in Chechnya, the early response provides an opportunity to plan and execute a program thoroughly, and incorporate lessons of past operations. AusAID personnel should also consider that the need for their intervention derives from institutional failure in PNG, and plan activities which will avoid prolonging this failure." Similarly, in Bougainville aid organisations have the opportunity to consider ways of working which will support local mechanisms and not hinder the peace process. Lessons can be drawn from Afghanistan, Liberia, Angola, Cambodia, Mozambique, Somalia and Rwanda. But are these experiences noted in AusAID evaluations, or were no such evaluations conducted?

\section{Conclusion}

The aim of this article is to stimulate debate in Australia about the dilemmas of humanitarian aid, and to promote operational approaches which will consider the broad impacts of the provision of emergency assistance. Rather than fearing that such a debate would discourage the public from supporting aid activities, it is possible that such honesty would gain sympathy for aid organisations and individuals who continue to work in disaster zones, and continue to risk their lives, in spite of all the difficulties.

There is vast international experience and knowledge of emergency response programs from which lessons can be drawn. Unfortunately, terms like 'complex emergency' serve to mask the historical similarities between the causes of humanitarian emergencies today and those of the past. This language encourages us to ignore the lessons of previous operations in allegedly 'simple' times. In reality, it is the omnipresence and multiplicity of aid organisations, responding in a spectrum of specialised sectors, which causes the complexity.

Donors can play a pivotal role in driving the debate about humanitarian aid and encouraging innovative responses to avoid the piffalls so often associated with aid provision in war. Donors should be encouraging appraisals of the context in which humanitarian aid is provided rather than focusing on the extent to which individual project objectives are met. AusAID's focus on financial and managerial accountability at the Australian level, however, is unlikely to inspire a debate about accountability to recipients: quite the reverse. The Simons Report emphasised the impor-

\footnotetext{
${ }^{4} \mathrm{I}$ am indebted to a referee for this point.
} 
tance of outcomes, and if 'risky' is interpreted from the perspective of beneficiaries rather than from that of investors, the recommendation is relevant to this discussion:

AusAID must refocus on results. Perhaps the single biggest shortcoming in the administration of the aid program is the lack of priority afforded to evaluation. Development assistance is an inherently risky business. It should not be made riskier still by insufficient rigour in appraising proposals and evaluating results. A more rigorous assessment of results would enable the organisation to learn from its experiences. Evaluation should also be the basis of accountability. (Committee of Review of the Australian Overseas Aid Program, 1997:7)

NGO Codes of Conduct, or an independent NGO ratings agency (McLeod, 1995) are, or could be, useful tools with which to ensure that NGOs conform to a standard of practice and principles which the aid community and donors expect. It is helpful for the public and donors to see comparisons among agencies on, for example, the share of funds sent directly to the field as opposed to that spent on administrative costs. But this is only the tip of the iceberg; what happens in the field, out of the public eye, is of crucial importance to the populations to whom the public and governments are directing their aid.

There are rarely answers to dilemmas posed by situations like that of providing aid to Bosnian enclaves. But concentrating on the 'humanitarian imperative' to save lives in isolation of the larger political picture can cost more lives in the long run. It is naive to believe that good intentions are enough to make a difference; agencies have a moral responsibility to ensure that their aid is going to those for whom it is intended, and does not become a tool of belligerent groups. The only way to work towards this is to have an open and continuous discussion so that the next generation of aid workers going to the field starts rather than finishes with the appropriate analytical tools necessary for working in humanitarian emergencies.

\section{References}

Australian Agency for International Development (AusAID) (1995), Review of the Effectiveness of NGO Programs, Canberra.

_ (1997a), Web site, hutp://www.ausaid.gov.au/australianaid/ozaid01.htm.

- (1997b), NGO Package of Information (unpublished document).

- (1997c), Accreditation Report Format, Part B (unpublished document).

Australian International Development Assistance Bureau (AIDAB) (1994), Review of Humanitarian Relief Programs, AGPS, Canberra. 


\section{Fiona Terry}

Brauman, R. (1995), L'action humanitaire: Un exposé pour comprendre, Un essai pour réflechir, Collection Dominos, Flammarion, Paris.

(1997), 'Foreword', pp. xix-xxvi in Médecins Sans Frontières, World in Crisis: The Politics of Survival at the end of the 20th Century, Routledge, London and New York.

Broughton, B. (1996a), Paper 1 of Food Add Review: Recommendations of 1994 Review of Humanitarian Relief Programs, AusAID Evaluation Paper, Canberra.

- (1996b), Paper 2 of Food Aid Review: Recent Evaluations of Humanitarian Food Aid, AusAID Evaluation Paper, Canberra.

Burkholder, B. \& M. Toole (1995), 'Evolution of Complex Disasters', The Lancet 365: 1012-15.

Camilleri, J. \& J. Falk (1992), End of Sovereignty?: The Politics of a Shrinking and Fragmenting World, Edward Elgar, Aldershot.

Committee to Review the Australian Overseas Aid Program (1997), One Clear Objective: Poverty Reduction through Sustainable Development, AGPS, Canberra (Simons Report).

Downer, Hon. A. (1997), Australia's Overseas Aid Program 1997-98, AGPS, Canberra (13 May).

Duffield, M. (1994), 'Complex Emergencies and the Crisis of Developmentalism', IDS Bulletin: Linking Relief and Development 25(4): 37-45.

Girardet, E. (1993), 'Public Opinion, the Media and Humanitarianism', pp. 39-55 in T. Weiss \& L. Minear (eds), Humanitarianism Across Borders: Sustaining Civilians in Times of War, Lynne Rienner, Boulder.

Hobbs, J. \& D. Goldsworthy (1996), 'Introduction', pp. xiii-xxi in P. Kilby (ed.), Australia's Aid Program: Mixed Messages and Conflicting Agendas, Monash Asia Institute and Community Aid Abroad, Melbourne.

Hunt, J. (1997), Executive Director of the Australian Council for Overseas Aid, personal communication.

International Federation of the Red Cross and Red Crescent Societies (IFRC) (1997), World Disasters Report 19.97, Oxford University Press, Oxford.

James, A. (1995), 'Peacekeeping, Peace-Enforcement and National Sovereignty', pp. 263-80 in R. Thakur \& C. Thayer (eds), A Crisis of Expectations: UN Peacekeeping in the 1990s, Westview, Boulder.

Jean, F. (1996), 'Aide humanitaire et économie de guerre', pp. 543-89 in F. Jean \& J-C. Rufin (eds) Économie des guerres civiles, Hachette, Paris.

Kaplan, R. (1994), 'The Coming Anarchy: How scarcity, crime, overpopulation, and disease are rapidly destroying the social fabric of our planet', Atlantic Monthly 273(2): 44-76.

McLeod, R. (1995), 'Getting Value for Money from the Overseas Aid Community', Agenda 2: 521-28.

Richards, P. (1996), Fighting for the Rain Forest: War, Youth and Resources in Sierra Leone, The International African Institute in association with James Currey, Oxford, and Heinemann, Portsmouth, New Hampshire.

Rufin, J-C. (1996), 'Les économies de guerre dans les conflits internes', pp. 19-59 in F. Jean \& J-C. Rufin (eds), Economie des guerres civiles, Hachette, Paris.

Urban, P. (1997), ‘One Clear Objective - but No Clear Approach', IPA Review 50(1): 9. 